$2-28-2017$

\title{
Corporate investment and stock liquidity: Evidence on the price impact of trade
}

\author{
Moonsoo Kang \\ Wei Wang \\ Cleveland State University, w.wang24@csuohio.edu \\ Chanyoung Eom
}

Follow this and additional works at: https://engagedscholarship.csuohio.edu/bus_facpub

Part of the Corporate Finance Commons, Economics Commons, and the Finance and Financial Management Commons

How does access to this work benefit you? Let us know!

\section{Publisher's Statement}

This is the author's version of a work that was accepted for publication in Review of Financial Economics. Changes resulting from the publishing process, such as peer review, editing, corrections, structural formatting, and other quality control mechanisms may not be reflected in this document. Changes may have been made to this work since it was submitted for publication. A definitive version was subsequently published in Review of Financial Economics, 33, (2017), 10.1016/j.rfe.2017.02.001.

\section{Recommended Citation}

Kang, Moonsoo; Wang, Wei; and Eom, Chanyoung, "Corporate investment and stock liquidity: Evidence on the price impact of trade" (2017). Business Faculty Publications. 286.

https://engagedscholarship.csuohio.edu/bus_facpub/286

This Article is brought to you for free and open access by the Monte Ahuja College of Business at EngagedScholarship@CSU. It has been accepted for inclusion in Business Faculty Publications by an authorized administrator of EngagedScholarship@CSU. For more information, please contact library.es@csuohio.edu. 


\title{
Corporate investment and stock liquidity: Evidence on the price impact of trade
}

\author{
Moonsoo Kang Wei Wang Chanyoung Eom
}

\begin{abstract}
A B S T R A C T
We document that corporate investment contributes to stock liquidity. This study demonstrates a positive relationship between abnormal corporate investment and stock liquidity in the cross-section. Moreover, stock liquidity improves more apparently for firms with financial constraints. Our robustness check confirms that the existing regularities cannot explain the current finding. This analysis suggests that corporate investment decreases the risk of a firm and that a change in the risk affects the behavior of a market maker, leading to an increase in stock liquidity.
\end{abstract}

Keywords:

Stock liquidity

Corporate investment

Financial constraints

\section{Introduction}

The recent corporate investment literature documents that optimal corporate investment changes the risk of a stock (Berk, Green, \& Naik, 1999). Then how does a change in the risk of a stock affect stock liquidity? The market microstructure literature addresses that a change in the risk affects the pricing strategy of market makers, leading to a change in the price impact, i.e. stock liquidity (Kyle, 1985). In this analysis, we establish a link between corporate investment and stock liquidity by connecting this line of corporate investment study to the market microstructure literature. Specifically, we provide empirical evidence on the role of corporate investment in shaping stock liquidity and argue that the risk shift from corporate investment contributes to stock liquidity.

We motivate the current study as follows. In their seminal paper, Berk et al. (1999) argue that corporate investment decision can be evaluated in a real options context because the decision to invest converts growth options into assets in place. Thus, if growth opportunities are finite, corporate investment decision changes the ratio of growth options to assets in place, i.e. the asset risk of a firm, leading to a change in the risk of its stock. In other words, the risk of a stock relates to current and historical investment decisions of the firm. (Carlson, Fisher, \& Giammarino, 2004) Specifically, optimal corporate investment decreases the risk of a stock, mostly its systematic part. Even when the new assets are risky, they are less risky than the options they replace. (Carlson, Fisher, \& Giammarino, 2006). ${ }^{1}$ This line of study contributes to the asset pricing literature by exploring the implications of corporate investment for the cross section and time series of expected returns. Berk et al. (1999) are among the first to construct a dynamic real options model by analyzing the risk change in the context of corporate investment. Carlson et al. (2004), Zhang (2005), Li, Livdan, and Zhang (2009), and Liu, Whited, and Zhang (2009) are in line with the model.

On the other hand, stock liquidity is endogenously determined. In particular, stock liquidity is governed by different trade motives such as private information (Kyle, 1985; Glosten \& Milgrom, 1985) and liquidity (Admati \& Pfleiderer, 1988). As both trade motives are subject to the risk of a stock, a change in the risk leads market makers to change the pricing strategy, affecting the price impact. Specifically, Kyle (1985) proposes that at the equilibrium, the risk of a stock shows a negative relationship with stock liquidity. Moreover, the recent liquidity literature provides evidence on a negative association between the systematic component of the risk and stock liquidity. ${ }^{2}$ Taken together, regardless of the risk source or structure, a change in the risk of a stock negatively $\mathrm{co}$-varies with stock liquidity.

\footnotetext{
1 Our robustness analysis shows that higher corporate investment leads to lower retum volatility, that is, lower risk. Therefore, corporate investment decreases the risk of a stock, which could be due to either idiosyncratic or systematic risk or both.

${ }^{2}$ Brunnermeier and Pedersen (2009) propose a differential effect of the market risk on high- and low-risk stocks while both Comerton-Forde et al. (2010) and Nagel (2012) empirically demonstrate that high-risk stocks are more prone to market-wide liquidity shocls.
} 
By combining these two lines of study, we can hypothesize that corporate investment affects stock liquidity through the pricing strategy of market makers. Specifically, we conjecture that optimal corporate investment improves stock liquidity by lowering the risk of a stock. To our best knowledge, this study is the first empirical analysis linking corporate investment to stock liquidity by emphasizing the risk shift from corporate investment.

To address this association, we develop a research design to capture the effect of an exogenous change in corporate investment on stock liquidity. Specifically, following Titman, Wei, and Xie (2005), we define corporate investment as the deviation from the prior three-year moving average corporate investment. This approach minimizes a firm-fixed effect by removing a persistent characteristic from a raw variable. Then, we employ abnormal corporate investment as an exogenous shock and investigate the cross-sectional relationship between abnormal corporate investment and subsequent stock liquidity. In the meantime, the literature addresses that there is the feedback effect of stock liquidity on corporate investment ${ }^{3}$ As a determinant of required returns (Acharya \& Pedersen, 2005), stock liquidity expands the set of profitable investment opportunities and increases corporate investment. (Derrien \& Kecskes, 2013: Becker-Blease \& Paul, 2006). Therefore, we also investigate if our analysis is subject to the endogeneity issue. ${ }^{4}$

Our empirical analysis shows that corporate investment indeed contributes to stock liquidity. First, a portfolio analysis illustrates that stock liquidity is significantly high for firms with a high level of corporate investment. Specifically, we sort a universe of stocks based on past stock liquidity and abnormal corporate investment every year. After a fiscal year ends, firms with a high level of corporate investment exhibit a high level of stock liquidity while firms with a low level of corporate investment present a low level of stock liquidity for both corporate investment measures. To comply with the corporate investment literature, we employ two measures for corporate investment: capital expenditure and capital expenditure plus R\&D.

Second, the cross-sectional regression analysis confirms the role of corporate investment in shaping subsequent stock liquidity. In particular, when we run the Fama and MacBeth (1973) type yearly crosssectional regression, abnormal corporate investment is positively associated with subsequent stock liquidity even after controlling for wellknown determinants such as past stock liquidity and several stock characteristics. This result holds for both corporate investment measures. We observe that this pattern lasts for three months after a fiscal year ends while it gets statistically weaker beyond the horizon.

Furthermore, we examine whether financial constraints have an impact on the relationship between corporate investment and stock liquidity. Since Fazzari, Hubbard, and Petersen (1988) address the effect of financial constraints on corporate investment, many studies investigate the relationship between imperfect capital market and corporate investment. ${ }^{5}$ As financial constraints prevent firms from financing all the desired investments, financially-constrained firms are less likely to respond to profitable investment opportunities, as shown in Kaplan and Zingales (1997). In other words, for the same level of corporate investment, investment opportunities are more likely to be profitable for financially-constrained firm than for financially-unconstrained firms other things equal. This intuition is consistent with a decreasing marginal productivity of investment opportunity. Therefore, we hypothesize that given any change in corporate investment, financially-constrained firms are likely to experience a greater risk shift and show a stronger effect on stock liquidity. ${ }^{6}$

\footnotetext{
${ }^{3}$ Bond, Edmans, and Goldstein (2012) provide an excellent survey on the feedback effect of stock market on the real economy.

${ }^{4}$ We thank the reviewer for pointing out this issue

5 See Hubbard (1998) and Stein (2003) for the classical corporate investment literature review.

${ }^{6}$ Whited and Wu (2006), Gomes et al. (2006), and Livdan, Shapriza, and Lu (2009) explain the relationship between financial constraints risk and stock returns.
}

Table 1

Descriptive statistics.

This table presents descriptive summary statistics for the data set. AMH is the logarithm of the Amihud (2002) daily liquidity measure which is an absolute daily return scaled by daily dollar trade volume measured over one month after the fiscal year ends. CAP (or CRD) is capital expenditure (plus R\&D), scaled by beginning-of-year assets and subtracted from the prior three-year moving average capital expenditure (plus R\&D). SIZE is the firm size defined as the logarithm of capitalization in the month that the fiscal year ends. PRC is the logarithm of a stock price in the month that the fiscal year ends. TNV is the average of the logarithm of daily turnover in the month that the fiscal year ends. VOL is the logarithm of the standard deviation of daily stock return in the month that the fiscal year ends. RET is a stock retum in the fiscal year. CB is cash balance, scaled by beginning-of-year assets. The sample spans the year of 1971 to 2012 .

\begin{tabular}{llllll}
\hline & Mean & Std. dev. & $1 \%$ & Median & $99 \%$ \\
\hline AMH & -16.579 & 2.624 & -22.355 & -16.587 & -10.919 \\
CAP & -0.012 & 0.197 & -0.270 & -0.005 & 0.220 \\
CRD & -0.014 & 0.251 & -0.349 & -0.006 & 0.271 \\
SIZE & 11.986 & 1.751 & 8.767 & 11.801 & 16.717 \\
PRC & 2.569 & 0.963 & 0.048 & 2.659 & 4.466 \\
TNV & -6.407 & 1.053 & -9.102 & -6.331 & -4.150 \\
VOL & -3.669 & 0.550 & -4.949 & -3.672 & -2.329 \\
RET & 0.174 & 0.620 & -0.678 & 0.072 & 2.383 \\
CB & 0.263 & 2.672 & 0.002 & 0.092 & 1.826 \\
\hline
\end{tabular}

Our analysis shows that corporate investment indeed exhibits a stronger effect on stock liquidity for financially-constrained firms. Using two financial constraints measures such as the Kaplan and Zingales (1997; KZ) index and firm size, we sort a universe of stocks on financial constraints every year and analyze these two groups separately. The cross-sectional analysis shows that it is financiallyconstrained firms such as high KZ-index or small firms that drive the association between corporate investment and stock liquidity. Specifically, high KZ-index or small firms exhibit a significant effect of corporate investment on stock liquidity while low KZ-index or big firms show a weaker effect. After all, confirming the effect of market frictions on corporate investment, this analysis shows that financial constraints indeed interact with corporate investment in shaping stock liquidity.

In the robustness check, we explore an alternative explanation for the corporate investment-stock liquidity relationship. First, we examine whether optimal corporate investment indeed decreases the risk of a stock. Given that corporate investment relates to mostly the systematic risk of a stock, one might question the effect of corporate investment on total risk and therefore the implication for stock liquidity. However, our analysis confirms that corporate investment indeed reduces the total risk of a stock. ${ }^{7}$ Second, we investigate the feedback effect of stock liquidity on corporate investment. Using the two-stage least square analysis (2SLS), we directly control for the endogeneity issue. The instrumental variable approach does not change the result of the original analysis. Third, we also control for net equity financing to see if eq uity financing explains the relationship between corporate investment and stock liquidity, as proposed by Eckbo, Masulis, and Norli (2000). Eckbo et al. (2000) argue that equity offering leads to an increase in stock liquidity, implying the effect of financing decision on stock liquidity. However, we find that corporate investment indeed improves stock liquidity, independent of equity financing. Overall, our robustness check confirms that corporate investment indeed contributes to stock liquidity.

Our study complements a growing study on the determinants of stock liquidity. The literature addresses several factors such as firm's characteristics (capitalization and stock price), trading activity (volume and information asymmetry), and market maker (funding liquidity). However, only a few studies explore the implication of firm's activity for stock liquidity. Among them are Eckbo et al. (2000) and Gopalan, Kadan, and Pevzner (2012). This study contributes to this line of research by discovering the role of corporate investment in shaping

\footnotetext{
${ }^{7}$ We thank the reviewer for pointing out this issue.
} 
Table 2

Correlations.

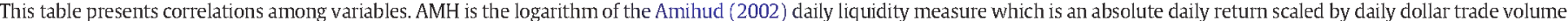

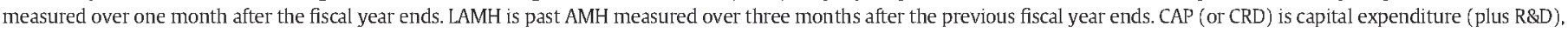

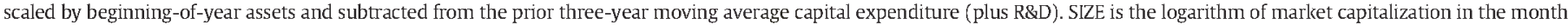

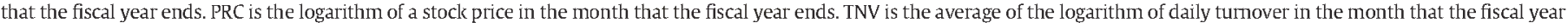

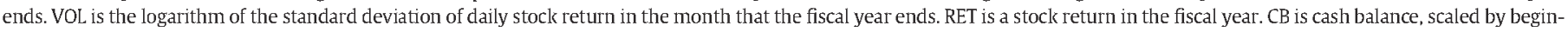
ning-of-year assets. The sample spans the year of 1971 to 2012.

\begin{tabular}{|c|c|c|c|c|c|c|c|c|c|}
\hline & LAMH & CAP & CRD & SIZE & PRC & TNV & VOL & RET & $\mathrm{CB}$ \\
\hline AMH & 0.919 & -0.042 & -0.036 & -0.921 & -0.756 & -0.529 & 0.403 & -0.193 & -0.026 \\
\hline LAMH & & -0.031 & -0.024 & -0.905 & -0.687 & -0.484 & 0.378 & 0.010 & -0.015 \\
\hline CAP & & & 0.871 & 0.036 & 0.084 & 0.000 & -0.051 & 0.097 & 0.072 \\
\hline CRD & & & & 0.032 & 0.080 & -0.007 & -0.050 & 0.100 & 0.080 \\
\hline SIZE & & & & & 0.763 & 0.276 & -0.447 & 0.141 & -0.008 \\
\hline PRC & & & & & & 0.178 & -0.569 & 0.285 & 0.018 \\
\hline TNV & & & & & & & 0.200 & 0.135 & 0.084 \\
\hline VOL & & & & & & & & -0.097 & 0.053 \\
\hline RET & & & & & & & & & 0.093 \\
\hline
\end{tabular}

stock liquidity. Moreover, our analysis is also relevant to the market efficiency literature because we can explore the link between corporate investment and market anomaly by highlighting the evolution of stock liquidity in response to a change in the risk attributable to corporate investment.

The rest of the paper is organized as follows. Section 2 presents data and preliminary analysis. Sections 3 discusses our main empirical analysis while Section 4 explains the robustness check. Finally, Section 5 concludes the paper.

\section{Data and primary analysis}

\subsection{Data}

We use common stocks (share code of 10 or 11) on the COMPUSTAT and CRSP data set over the period of 1971 to $2012 .^{8}$ Conforming to the investment literature (Baker, Stein, \& Wurgler, 2003), our analysis includes those stocks whose book equity is greater than 10 million dollars while it excludes regulated or financial firms, those firms whose primary SIC classification is between 4900 and 4999 or between 6000 and 6999, as the investment literature does. As a result, the sample contains total 74,280 firm-year observations, on average 1768 firms per year.

Table 1 reports descriptive statistics. A measure of stock liquidity is AMH, the logarithm of the Amihud (2002) daily illiquidity measure which is an absolute daily return scaled by daily dollar trade volume measured over one month after the fiscal year ends. Amihud (2002) argues that $\mathrm{AMH}$ is interpreted as daily price response associated with one dollar of trading volume, thus serving a rough measure of the price impact of the Kyle (1985)'s $\lambda$. Kyle (1985) demonstrates that a market maker sets an equilibrium price by following his pricing strategy and determining the price impact, the Kyle (1985)'s $\lambda$. In the dataset, AMH varies from -22.355 to -10.919 . CAP (or CRD) is our main explanatory variable for corporate investment. Following Titman et al. (2005), we define corporate investment as the deviation from the prior three-year moving average corporate investment. Specifically, CAP (or CRD) is capital expenditures, Compustat Item 128 (plus R\&D, Item 46), scaled by beginning-ofyear book assets (Item 6) and subtracted from the prior three-year moving average capital expenditure (plus R\&D).

We use several control variables. SIZE is the firm size defined as the logarithm of capitalization in the month that the fiscal year ends. PRC is the logarithm of a stock price in the month that the fiscal year ends. TNV is the average of the logarithm of daily turnover in the month that the fiscal year ends. VOL is the logarithm of the standard deviation of daily stock return in the month that the fiscal year ends. RET is a stock return

\footnotetext{
${ }^{8}$ We exclude the pre-1971 data because of a small number of observations.
}

over the fiscal year. We also add CB to capture the effect of asset liquidity, as shown in Gopalan et al. (2012). CB is cash balance (Item 1), scaled by beginning-of-year assets.

Table 2 presents correlations among variables. AMH is very persistent with a correlation of 0.919 with past AMH, measured over three months after the previous fiscal year ends, consistent with the liquidity literature. ${ }^{9}$ AMH varies with firm size, stock price level, and trade volume, as addressed in the literature. We also find that high return volatility harms stock liquidity while high stock return benefits stock liquidity. This observation is consistent with inventory risk and funding liquidity (Grossman \& Miller, 1988; Brunnermeier \& Pedersen, 2009)..$^{10}$ Moreover, stock liquidity increases in asset liquidity, $C B$, consistent with Gopalan et al. (2012). Finally, both CAP and CRD are weakly correlated with AMH. CAP shows a correlation of -0.042 with AMH while CRD exhibits a correlation of $-0.036 .{ }^{11}$ However, corporate investment shows a relatively strong association with stock return with a correlation of 0.097 or 0.100 , consistent with Eisfeldt (2004).

\subsection{Preliminary analysis}

As a preliminary analysis, we examine how corporate investment affects subsequent stock liquidity in two ways. The first analysis focuses on the behavior of stock liquidity over time while the second one shows a two-way sorting portfolio analysis.

In the first analysis, we present two figures showing a series of monthly stock liquidity for portfolios formed on corporate investment. First, we form portfolios by sorting stocks based on abnormal corporate investment in the fiscal year and dividing them into three terciles. ${ }^{12} \mathrm{Sec}-$ ond, we calculate subsequent stock liquidity, AMH, for each portfolio over six months after the fiscal year ends. ${ }^{13}$ The results are shown in Figs. 1 and 2 which illustrate the behavior of stock liquidity from the bottom tercile with low CAP or CRD (P1) to the top tercile with high CAP or CRD (P3). In Figs. 1 and 2, we observe that corporate investment contributes to subsequent stock liquidity. That is, high corporate investment leads to high stock liquidity. This pattern persists over the following six months. Interestingly, we also find that stock liquidity on average improves over time regardless of a level of corporate investment.

\footnotetext{
${ }^{9}$ To separate the effect of prior corporate investment from that of the current one, we estimate past stock liquidity over three months after the previous fiscal year ends. We obtain similar results for the six or other month window.

${ }^{10}$ However, past stock liquidity, LAMH, shows a weak positive association with stock return.

${ }^{11}$ A nominal capital expenditure (plus R\&D) measure, not an abnormal one, is also positively related to stock liquidity, with a correlation of -0.099 (or -0.100 ) with AMH based on unreported analysis.

${ }^{12}$ We obtain similar results for the formation methods based on different number of portfolios.

${ }^{13}$ Therefore, our analysis is an event study.
} 
CAP

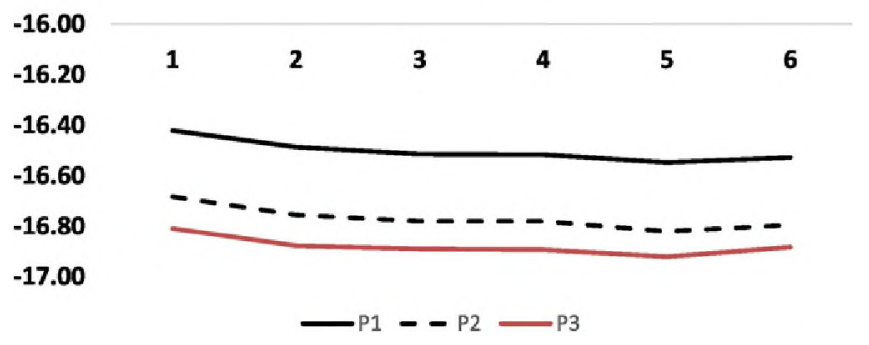

Fig. 1. Stock liquidity for portfolios based on corporate investment (CAP). Fig. 1 describes the behavior of subsequent stock liquidity, $\mathrm{AMH}$, measured over six months after the fiscal year ends, for each portfolio formed on abnormal corporate investment (CAP). P1 presents the bottom tercile with low CAP, while P3 shows the top tercile with high CAP.

In the second analysis, we report the result for a two-way sorting portfolio analysis. Considering the persistence of stock liquidity, as shown in Table 2, we control for past stock liquidity to examine if corporate investment is indeed associated with subsequent stock liquidity. Therefore, we sort stocks into five liquidity portfolios (from LIQ to ILLIQ) based on past AMH. Then, we divide each liquidity portfolio into either High or Low corporate investment subgroup. Finally, we measure subsequent stock liquidity for each portfolio over six months after the fiscal year ends. The results are presented in Table 3 where Panels $A$ and $B$ show our analysis, based on CAP and CRD respectively.

As expected, stock liquidity is strongly associated with past stock liquidity. That is, when past stock liquidity is high, current stock liquidity is also high. More importantly, stock liquidity increases in corporate investment even for the same level of past stock liquidity. We find a significant difference in stock liquidity between High and Low portfolios, regardless of a level of past stock liquidity. Moreover, this pattern persists over time for both CAP and CRD. Overall, our primary analysis provides basic empirical evidence on the relationship between corporate investment and subsequent stock liquidity, i.e. a positive association.

\section{Empirical analysis}

\subsection{Corporate investment and stock liquidity}

In this section, we formally examine the effect of corporate investment on stock liquidity by using the Fama and Macbeth (1973) crosssectional regression analysis. ${ }^{14}$ Specifically, we analyze the crosssectional relationship between abnormal corporate investment and subsequent stock liquidity in a yearly regression for the sample period of 1971 to 2012 . Our estimation model for stock liquidity is as follows.

$$
\begin{aligned}
A M H_{i, t}=\alpha_{t} & +\beta_{1} I N V_{i, t-1}+\gamma_{1} L_{A M H_{i, t-1}}+\gamma_{2} S_{Z I E E_{i, t-1}}+\gamma_{3} P R C_{i, t-1} \\
& +\gamma_{4} T V_{i, t-1}+\gamma_{5} V O L_{i, t-1}+\gamma_{6} R E T_{i, t-1}+\gamma_{7} C B_{i, t-1}+\eta_{i, t}
\end{aligned}
$$

In the analysis, we include abnormal corporate investment as a main independent variable along with several stock liquidity determinants such as past stock liquidity and stock characteristics. We use abnormal corporate investment to control for the feedback effect of stock liquidity on corporate investment. According to the literature, stock liquidity expands the set of profitable investment opportunities and increases corporate investment (Derrien \& Kecskes, 2013; Becker-Blease \& Paul, 2006). Therefore, considering the feedback effect, we attempt to capture the effect of an exogenous change in corporate investment on stock liquidity. In particular, following Titman et al. (2005), we define an exogenous change in corporate investment as the deviation from the prior

\footnotetext{
${ }^{14}$ The panel regression analysis provides qualitatively the same evidence as the crosssectional analysis does.
}

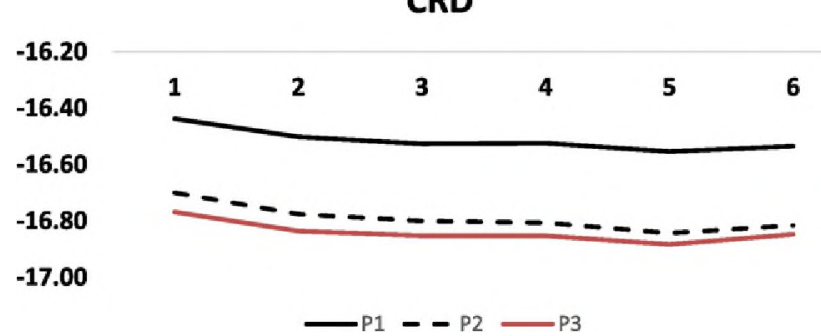

Fig. 2. Stock liquidity for portfolios based on corporate investment (CRD). Fig. 2 describes the behavior of subsequent stock liquidity, $\mathrm{AMH}$, measured over six months after the fiscal year ends, for each portfolio formed on abnormal corporate investment (CRD). P1 presents the bottom tercile with low CRD, while P3 shows the top tercile with high CRD.

three-year moving average corporate investment. Moreover, we also control for the feedback effect by including past stock liquidity. In other words, given the persistence of stock liquidity, the presence of past stock liquidity can exclude the possibility that corporate investment reflects just past stock liquidity. In this regression setting, we repeat the analysis for stock liquidity measured over different months after the fiscal year ends. ${ }^{15}$

Table 4 exhibits the empirical analysis. We confirm many exiting regularities and summarize them as follows. First, past stock liquidity is strongly related to current stock liquidity with the coefficient of 0.130 to 0.163 and a t-statistic of 8.74 to 10.12 . This result confirms the persistence of stock liquidity, consistent with our analysis in Table 2 and the liquidity literature. Second, both firm size and stock price contribute to stock liquidity, as shown in the negative coefficients. When firm size (or stock price) is big (or high), firm enjoys high stock liquidity. Those stocks are known to have high stock liquidity. Third, both turnover and return volatility also govern stock liquidity. Specifically, stocks with high turnover and low volatility exhibit high stock liquidity. We observe this because market makers bear a low level of inventory risk for those stocks so that they provide more stock liquidity (Grossman \& Miller, 1988). Our analysis confirms the literature. Fourth, cash balance positively relates to stock liquidity. As Gopalan et al. (2012) show, firms with a high level of liquid asset show a high level of stock liquidity. That is, the coefficients of $\mathrm{CB}$, cash balance, are significantly negative, consistent with Gopalan et al. (2012).

Moreover, we observe that funding liquidity matters to stock liquidity as well. In other words, high funding liquidity, measured by high stock return, leads to high stock liquidity, as shown in the negative coefficients of RET. ${ }^{16}$ This analysis is consistent with the intuition of Brunnermeier and Pedersen (2009). In the meantime, we also interpret this finding in a different context. That is, one can argue that stock liquidity improves due to high stock performance, not corporate investment, because high corporate investment usually accompanies high stock return (Eisfeldt, 2004). Thus, we address this issue by examining whether corporate investment still has an independent effect on stock liquidity after controlling for high stock return. After all, our finding demonstrates that a good market condition itself indeed affects stock liquidity. However, we argue that corporate investment also contributes to stock liquidity independently, as addressed below.

Finally, we find that corporate investment indeed contributes to stock liquidity. That is, corporate investment significantly improves stock liquidity, as shown in the negative coefficient of INV. For example, the coefficient of INV is -0.069 (or -0.055 ) with a t-statistic of -2.35

\footnotetext{
15 In this sense, our analysis is similar to an event study.

${ }^{16}$ We interpret RET as a measure for firm-specific funding liquidity for market makers. A popular measure for funding liquidity is the TED spread, defined as three-month USD LIBOR rate minus US Treasury bill yield. However, the TED spread is suitable for marketwide funding liquidity, not for firm-specific funding liquidity. We believe that past stock return, RET, is more likely to reflect the cross-sectional variation in funding liquidity because traders or market makers can pledge the relevant security itself as collateral to obtain financing.
} 
Table 3

Stock liquidity sorted on past stock liquidity and corporate investment

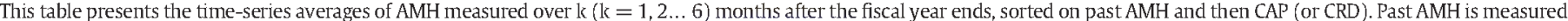

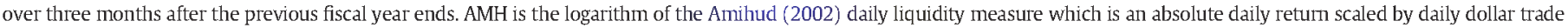

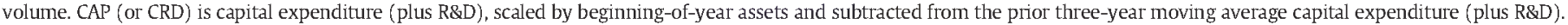
The difference in AMH between Low and High CAP (or CRD) portfolios is also reported, along with $t$-statistics in parentheses. The sample spans the year of 1971 to 2012.

\begin{tabular}{|c|c|c|c|c|c|c|c|c|c|}
\hline & \multicolumn{9}{|c|}{ Panel A: CAP } \\
\hline & \multicolumn{3}{|l|}{1 month } & \multicolumn{3}{|l|}{2 month } & \multicolumn{3}{|l|}{3 month } \\
\hline & Low & High & Diff & Low & High & Diff & Low & High & Diff \\
\hline LIQ & $\begin{array}{l}-20.206 \\
(-73.37)\end{array}$ & $\begin{array}{l}-20.301 \\
(-74.31)\end{array}$ & $\begin{array}{l}-0.095 \\
(-3.23)\end{array}$ & $\begin{array}{l}-20.233 \\
(-73.26)\end{array}$ & $\begin{array}{l}-20.333 \\
(-74.37)\end{array}$ & $\begin{array}{l}-0.100 \\
(-3.39)\end{array}$ & $\begin{array}{l}-20.238 \\
(-73.42)\end{array}$ & $\begin{array}{l}-20.336 \\
(-74.49)\end{array}$ & $\begin{array}{l}-0.097 \\
(-3.36)\end{array}$ \\
\hline 2 & $\begin{array}{l}-17.945 \\
(-65.76)\end{array}$ & $\begin{array}{l}-18.066 \\
(-66.20)\end{array}$ & $\begin{array}{l}-0.121 \\
(-5.87)\end{array}$ & $\begin{array}{l}-17.982 \\
(-65.56)\end{array}$ & $\begin{array}{l}-18.106 \\
(-66.28)\end{array}$ & $\begin{array}{l}-0.124 \\
(-6.53)\end{array}$ & $\begin{array}{l}-17.993 \\
(-65.45)\end{array}$ & $\begin{array}{l}-18.116 \\
(-66.39)\end{array}$ & $\begin{array}{l}-0.122 \\
(-6.66)\end{array}$ \\
\hline 3 & $\begin{array}{l}-16.531 \\
(-63.38)\end{array}$ & $\begin{array}{l}-16.654 \\
(-65.55)\end{array}$ & $\begin{array}{l}-0.123 \\
(-5.05)\end{array}$ & $\begin{array}{l}-16.561 \\
(-63.69)\end{array}$ & $\begin{array}{l}-16.688 \\
(-65.80)\end{array}$ & $\begin{array}{l}-0.127 \\
(-5.28)\end{array}$ & $\begin{array}{l}-16.579 \\
(-63.71)\end{array}$ & $\begin{array}{l}-16.702 \\
(-65.59)\end{array}$ & $\begin{array}{l}-0.123 \\
(-5.23)\end{array}$ \\
\hline 4 & $\begin{array}{l}-15.140 \\
(-67.84)\end{array}$ & $\begin{array}{l}-15.258 \\
(-67.37)\end{array}$ & $\begin{array}{l}-0.118 \\
(-4.19)\end{array}$ & $\begin{array}{l}-15.174 \\
(-68.40)\end{array}$ & $\begin{array}{l}-15.292 \\
(-68.38)\end{array}$ & $\begin{array}{l}-0.118 \\
(-4.19)\end{array}$ & $\begin{array}{l}-15.198 \\
(-68.32)\end{array}$ & $\begin{array}{l}-15.317 \\
(-68.49)\end{array}$ & $\begin{array}{l}-0.119 \\
(-4.23)\end{array}$ \\
\hline \multirow[t]{4}{*}{ ILLIQ } & $\begin{array}{l}-13.273 \\
(-73.93)\end{array}$ & $\begin{array}{l}-13.411 \\
(-76.49)\end{array}$ & $\begin{array}{l}-0.138 \\
(-5.01)\end{array}$ & $\begin{array}{l}-13.313 \\
(-75.21)\end{array}$ & $\begin{array}{l}-13.452 \\
(-78.24)\end{array}$ & $\begin{array}{l}-0.139 \\
(-5.20)\end{array}$ & $\begin{array}{l}-13.350 \\
(-75.70)\end{array}$ & $\begin{array}{l}-13.494 \\
(-78.55)\end{array}$ & $\begin{array}{l}-0.143 \\
(-5.27)\end{array}$ \\
\hline & \multicolumn{9}{|c|}{ Panel A: CAP } \\
\hline & \multicolumn{3}{|l|}{4 month } & \multicolumn{3}{|l|}{5 month } & \multicolumn{3}{|l|}{6 month } \\
\hline & Low & High & Diff & Low & High & Diff & Low & High & Diff \\
\hline LIQ & $\begin{array}{l}-20.239 \\
(-73.41)\end{array}$ & $\begin{array}{l}-20.336 \\
(-74.50)\end{array}$ & $\begin{array}{l}-0.096 \\
(-3.32)\end{array}$ & $\begin{array}{l}-20.245 \\
(-73.31)\end{array}$ & $\begin{array}{l}-20.341 \\
(-74.49)\end{array}$ & $\begin{array}{l}-0.096 \\
(-3.29)\end{array}$ & $\begin{array}{l}-20.244 \\
(-73.32)\end{array}$ & $\begin{array}{l}-20.341 \\
(-74.49)\end{array}$ & $\begin{array}{l}-0.097 \\
(-3.36)\end{array}$ \\
\hline 2 & $\begin{array}{l}-17.997 \\
(-65.51)\end{array}$ & $\begin{array}{l}-18.118 \\
(-66.53)\end{array}$ & $\begin{array}{l}-0.121 \\
(-6.49)\end{array}$ & $\begin{array}{l}-18.003 \\
(-65.20)\end{array}$ & $\begin{array}{l}-18.121 \\
(-66.32)\end{array}$ & $\begin{array}{l}-0.118 \\
(-6.23)\end{array}$ & $\begin{array}{l}-18.003 \\
(-65.08)\end{array}$ & $\begin{array}{l}-18.116 \\
(-66.33)\end{array}$ & $\begin{array}{l}-0.113 \\
(-6.10)\end{array}$ \\
\hline 3 & $\begin{array}{l}-16.586 \\
(-63.99)\end{array}$ & $\begin{array}{l}-16.707 \\
(-65.66)\end{array}$ & $\begin{array}{l}-0.121 \\
(-5.17)\end{array}$ & $\begin{array}{l}-16.598 \\
(-63.92)\end{array}$ & $\begin{array}{l}-16.715 \\
(-65.44)\end{array}$ & $\begin{array}{l}-0.117 \\
(-5.02)\end{array}$ & $\begin{array}{l}-16.601 \\
(-63.80)\end{array}$ & $\begin{array}{l}-16.715 \\
(-65.24)\end{array}$ & $\begin{array}{l}-0.114 \\
(-4.84)\end{array}$ \\
\hline 4 & $\begin{array}{l}-15.208 \\
(-68.34)\end{array}$ & $\begin{array}{l}-15.328 \\
(-68.54)\end{array}$ & $\begin{array}{l}-0.120 \\
(-4.40)\end{array}$ & $\begin{array}{l}-15.216 \\
(-68.32)\end{array}$ & $\begin{array}{l}-15.338 \\
(-68.38)\end{array}$ & $\begin{array}{l}-0.121 \\
(-4.64)\end{array}$ & $\begin{array}{l}-15.218 \\
(-68.15)\end{array}$ & $\begin{array}{l}-15.339 \\
(-68.13)\end{array}$ & $\begin{array}{l}-0.121 \\
(-4.89)\end{array}$ \\
\hline \multirow[t]{4}{*}{ ILLIQ } & $\begin{array}{l}-13.374 \\
(-76.44)\end{array}$ & $\begin{array}{l}-13.522 \\
(-78.65)\end{array}$ & $\begin{array}{l}-0.148 \\
(-5.45)\end{array}$ & $\begin{array}{l}-13.395 \\
(-77.09)\end{array}$ & $\begin{array}{l}-13.546 \\
(-78.41)\end{array}$ & $\begin{array}{l}-0.151 \\
(-5.32)\end{array}$ & $\begin{array}{l}-13.407 \\
(-77.76)\end{array}$ & $\begin{array}{l}-13.552 \\
(-78.63)\end{array}$ & $\begin{array}{l}-0.145 \\
(-4.95)\end{array}$ \\
\hline & \multicolumn{9}{|c|}{ Panel B: CRD } \\
\hline & \multicolumn{3}{|l|}{1 month } & \multicolumn{3}{|l|}{2 month } & \multicolumn{3}{|l|}{3 month } \\
\hline & Low & High & Diff & Low & High & Diff & Low & High & Diff \\
\hline LIQ & $\begin{array}{l}-20.202 \\
(-73.51)\end{array}$ & $\begin{array}{l}-20.306 \\
(-74.17)\end{array}$ & $\begin{array}{c}-0.104 \\
(-3.59)\end{array}$ & $\begin{array}{l}-20.230 \\
(-73.46)\end{array}$ & $\begin{array}{l}-20.336 \\
(-74.17)\end{array}$ & $\begin{array}{l}-0.106 \\
(-3.67)\end{array}$ & $\begin{array}{l}-20.236 \\
(-73.60)\end{array}$ & $\begin{array}{l}-20.339 \\
(-74.31)\end{array}$ & $\begin{array}{l}-0.103 \\
(-3.58)\end{array}$ \\
\hline 2 & $\begin{array}{l}-17.940 \\
(-65.52)\end{array}$ & $\begin{array}{l}-18.072 \\
(-66.43)\end{array}$ & $\begin{array}{l}-0.132 \\
(-6.03)\end{array}$ & $\begin{array}{l}-17.976 \\
(-65.36)\end{array}$ & $\begin{array}{l}-18.112 \\
(-66.46)\end{array}$ & $\begin{array}{l}-0.137 \\
(-6.40)\end{array}$ & $\begin{array}{l}-17.986 \\
(-65.27)\end{array}$ & $\begin{array}{l}-18.123 \\
(-66.55)\end{array}$ & $\begin{array}{l}-0.137 \\
(-6.48)\end{array}$ \\
\hline 3 & $\begin{array}{l}-16.519 \\
(-63.48)\end{array}$ & $\begin{array}{l}-16.666 \\
(-65.43)\end{array}$ & $\begin{array}{l}-0.148 \\
(-5.92)\end{array}$ & $\begin{array}{l}-16.550 \\
(-63.80)\end{array}$ & $\begin{array}{l}-16.699 \\
(-65.67)\end{array}$ & $\begin{array}{l}-0.148 \\
(-6.01)\end{array}$ & $\begin{array}{l}-16.568 \\
(-63.84)\end{array}$ & $\begin{array}{l}-16.713 \\
(-65.44)\end{array}$ & $\begin{array}{l}-0.144 \\
(-5.92)\end{array}$ \\
\hline 4 & $\begin{array}{l}-15.133 \\
(-67.95)\end{array}$ & $\begin{array}{l}-15.265 \\
(-67.27)\end{array}$ & $\begin{array}{l}-0.132 \\
(-4.72)\end{array}$ & $\begin{array}{l}-15.163 \\
(-68.60)\end{array}$ & $\begin{array}{l}-15.303 \\
(-68.21)\end{array}$ & $\begin{array}{l}-0.139 \\
(-5.15)\end{array}$ & $\begin{array}{l}-15.187 \\
(-68.47)\end{array}$ & $\begin{array}{l}-15.329 \\
(-68.37)\end{array}$ & $\begin{array}{l}-0.142 \\
(-5.35)\end{array}$ \\
\hline \multirow[t]{4}{*}{ ILLIQ } & $\begin{array}{l}-13.269 \\
(-74.02)\end{array}$ & $\begin{array}{l}-13.415 \\
(-76.41)\end{array}$ & $\begin{array}{l}-0.146 \\
(-5.47)\end{array}$ & $\begin{array}{l}-13.309 \\
(-75.29)\end{array}$ & $\begin{array}{l}-13.456 \\
(-78.21)\end{array}$ & $\begin{array}{l}-0.147 \\
(-5.88)\end{array}$ & $\begin{array}{l}-13.349 \\
(-75.79)\end{array}$ & $\begin{array}{l}-13.495 \\
(-78.54)\end{array}$ & $\begin{array}{l}-0.147 \\
(-5.85)\end{array}$ \\
\hline & \multicolumn{9}{|c|}{ Panel B: CRD } \\
\hline & \multicolumn{3}{|l|}{4 month } & \multicolumn{3}{|l|}{5 month } & \multicolumn{3}{|l|}{6 month } \\
\hline & Low & High & Diff & Low & High & Diff & Low & High & Diff \\
\hline LIQ & $\begin{array}{l}-20.236 \\
(-73.59)\end{array}$ & $\begin{array}{l}-20.338 \\
(-74.30)\end{array}$ & $\begin{array}{l}-0.102 \\
(-3.49)\end{array}$ & $\begin{array}{l}-20.241 \\
(-73.59)\end{array}$ & $\begin{array}{l}-20.345 \\
(-74.19)\end{array}$ & $\begin{array}{l}-0.104 \\
(-3.55)\end{array}$ & $\begin{array}{l}-20.240 \\
(-73.63)\end{array}$ & $\begin{array}{l}-20.345 \\
(-74.16)\end{array}$ & $\begin{array}{l}-0.105 \\
(-3.61)\end{array}$ \\
\hline 2 & $\begin{array}{l}-17.989 \\
(-65.36)\end{array}$ & $\begin{array}{l}-18.125 \\
(-66.67)\end{array}$ & $\begin{array}{l}-0.136 \\
(-6.61)\end{array}$ & $\begin{array}{l}-17.994 \\
(-65.09)\end{array}$ & $\begin{array}{l}-18.130 \\
(-66.42)\end{array}$ & $\begin{array}{l}-0.136 \\
(-6.79)\end{array}$ & $\begin{array}{l}-17.993 \\
(-65.00)\end{array}$ & $\begin{array}{l}-18.126 \\
(-66.41)\end{array}$ & $\begin{array}{l}-0.133 \\
(-6.70)\end{array}$ \\
\hline 3 & $\begin{array}{l}-16.576 \\
(-64.12)\end{array}$ & $\begin{array}{l}-16.717 \\
(-65.52)\end{array}$ & $\begin{array}{l}-0.141 \\
(-5.86)\end{array}$ & $\begin{array}{l}-16.589 \\
(-64.00)\end{array}$ & $\begin{array}{l}-16.723 \\
(-65.35)\end{array}$ & $\begin{array}{l}-0.134 \\
(-5.59)\end{array}$ & $\begin{array}{l}-16.594 \\
(-63.88)\end{array}$ & $\begin{array}{l}-16.723 \\
(-65.15)\end{array}$ & $\begin{array}{l}-0.128 \\
(-5.40)\end{array}$ \\
\hline 4 & $\begin{array}{l}-15.195 \\
(-68.47)\end{array}$ & $\begin{array}{l}-15.341 \\
(-68.45)\end{array}$ & $\begin{array}{l}-0.146 \\
(-5.66)\end{array}$ & $\begin{array}{l}-15.204 \\
(-68.39)\end{array}$ & $\begin{array}{l}-15.350 \\
(-68.35)\end{array}$ & $\begin{array}{l}-0.146 \\
(-6.03)\end{array}$ & $\begin{array}{l}-15.204 \\
(-68.24)\end{array}$ & $\begin{array}{l}-15.352 \\
(-68.08)\end{array}$ & $\begin{array}{l}-0.148 \\
(-6.38)\end{array}$ \\
\hline ILLIQ & $\begin{array}{l}-13.373 \\
(-76.49)\end{array}$ & $\begin{array}{l}-13.522 \\
(-78.68)\end{array}$ & $\begin{array}{l}-0.149 \\
(-6.01)\end{array}$ & $\begin{array}{l}-13.395 \\
(-77.10)\end{array}$ & $\begin{array}{l}-13.546 \\
(-78.52)\end{array}$ & $\begin{array}{l}-0.151 \\
(-6.03)\end{array}$ & $\begin{array}{l}-13.404 \\
(-77.97)\end{array}$ & $\begin{array}{l}-13.555 \\
(-78.57)\end{array}$ & $\begin{array}{l}-0.151 \\
(-5.76)\end{array}$ \\
\hline
\end{tabular}

(or - 2.12) for CAP (or CRD) when AMH is measured over one month after the fiscal year ends. Moreover, we observe the same pattern for AMH measured over up to three months after the fiscal year ends. ${ }^{17}$ In

\footnotetext{
17 In the analysis of AMH measured over four to six months, we find significant results for CAP while obtaining weaker results for CRD, unlike the portfolio analysis in Table 3. The results are available upon request.
}

addition to a statistical significance, the contribution of corporate investment is also economically substantial. In other words, when a firm increases corporate investment by one standard deviation, stock liquidity increases by $7.7 \%$ for CAP and $7.9 \%$ for CRD respectively, as estimated by AMH. After all, this finding suggests that corporate investment plays a significant role in determining stock liquidity over a certain period of time, which is independent of many well-known determinants for stock liquidity. 
Table 4

Corporate investment and stock liquidity: cross-sectional analysis.

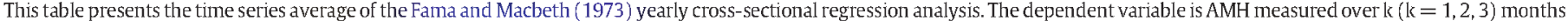

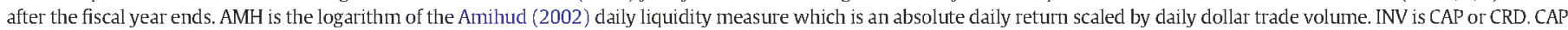

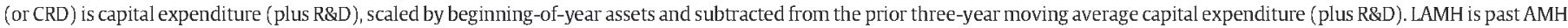

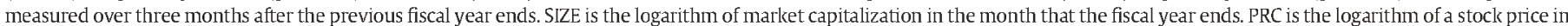

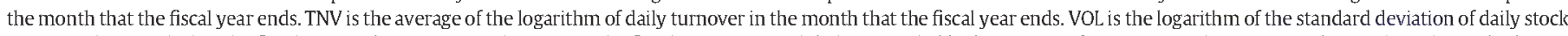

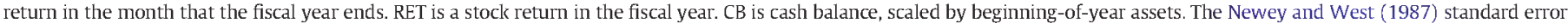
corrected $t$-statistics are presented in parentheses. The sample spans the year of 1971 to 2012 .

\begin{tabular}{|c|c|c|c|c|c|c|}
\hline & \multicolumn{3}{|l|}{$\mathrm{CAP}$} & \multicolumn{3}{|l|}{ CRD } \\
\hline & 1 month & 2 month & 3 month & 1 month & 2 month & 3 month \\
\hline Const. & $\begin{array}{l}-6.200 \\
(-33.77)\end{array}$ & $\begin{array}{l}-5.933 \\
(-34.43)\end{array}$ & $\begin{array}{l}-5.793 \\
(-33.32)\end{array}$ & $\begin{array}{l}-6.200 \\
(-33.77)\end{array}$ & $\begin{array}{l}-5.933 \\
(-34.43)\end{array}$ & $\begin{array}{l}-5.794 \\
(-33.32)\end{array}$ \\
\hline INV & $\begin{array}{l}-0.069 \\
(-2.35)\end{array}$ & $\begin{array}{l}-0.071 \\
(-2.15)\end{array}$ & $\begin{array}{l}-0.087 \\
(-2.45)\end{array}$ & $\begin{array}{l}-0.055 \\
(-2.12)\end{array}$ & $\begin{array}{l}-0.056 \\
(-1.83)\end{array}$ & $\begin{array}{l}-0.065 \\
(-1.93)\end{array}$ \\
\hline LAMH & $\begin{array}{l}0.130 \\
(8.74)\end{array}$ & $\begin{array}{l}0.152 \\
(9.77)\end{array}$ & $\begin{array}{l}0.163 \\
(10.12)\end{array}$ & $\begin{array}{l}0.130 \\
(8.74)\end{array}$ & $\begin{array}{l}0.152 \\
(9.78)\end{array}$ & $\begin{array}{l}0.163 \\
(10.12)\end{array}$ \\
\hline SIZE & $\begin{array}{l}-0.908 \\
(-57.18)\end{array}$ & $\begin{array}{l}-0.888 \\
(-54.40)\end{array}$ & $\begin{array}{l}-0.875 \\
(-51.63)\end{array}$ & $\begin{array}{l}-0.908 \\
(-57.15)\end{array}$ & $\begin{array}{l}-0.888 \\
(-54.41)\end{array}$ & $\begin{array}{l}-0.875 \\
(-51.64)\end{array}$ \\
\hline PRC & $\begin{array}{l}-0.246 \\
(-9.35)\end{array}$ & $\begin{array}{l}-0.242 \\
(-9.71)\end{array}$ & $\begin{array}{l}-0.240 \\
(-9.80)\end{array}$ & $\begin{array}{l}-0.246 \\
(-9.36)\end{array}$ & $\begin{array}{l}-0.242 \\
(-9.71)\end{array}$ & $\begin{array}{l}-0.240 \\
(-9.81)\end{array}$ \\
\hline TNV & $\begin{array}{l}-0.770 \\
(-62.16)\end{array}$ & $\begin{array}{l}-0.730 \\
(-54.22)\end{array}$ & $\begin{array}{l}-0.701 \\
(-48.20)\end{array}$ & $\begin{array}{l}-0.770 \\
(-62.15)\end{array}$ & $\begin{array}{l}-0.730 \\
(-54.23)\end{array}$ & $\begin{array}{l}-0.701 \\
(-48.21)\end{array}$ \\
\hline VOL & $\begin{array}{l}0.437 \\
(16.45)\end{array}$ & $\begin{array}{l}0.414 \\
(15.71)\end{array}$ & $\begin{array}{l}0.401 \\
(14.86)\end{array}$ & $\begin{array}{l}0.437 \\
(16.43)\end{array}$ & $\begin{array}{l}0.414 \\
(15.69)\end{array}$ & $\begin{array}{l}0.401 \\
(14.84)\end{array}$ \\
\hline RET & $\begin{array}{l}-0.162 \\
(-5.01)\end{array}$ & $\begin{array}{l}-0.179 \\
(-5.41)\end{array}$ & $\begin{array}{l}-0.184 \\
(-5.96)\end{array}$ & $\begin{array}{l}-0.162 \\
(-5.01)\end{array}$ & $\begin{array}{l}-0.179 \\
(-5.41)\end{array}$ & $\begin{array}{l}-0.184 \\
(-5.97)\end{array}$ \\
\hline $\mathrm{CB}$ & $\begin{array}{l}-0.040 \\
(-2.11)\end{array}$ & $\begin{array}{l}-0.053 \\
(-2.52)\end{array}$ & $\begin{array}{l}-0.057 \\
(-2.42)\end{array}$ & $\begin{array}{l}-0.041 \\
(-2.13)\end{array}$ & $\begin{array}{l}-0.053 \\
(-2.56)\end{array}$ & $\begin{array}{l}-0.058 \\
(-2.47)\end{array}$ \\
\hline Adj. R-squated (\%) & 95.8 & 96.0 & 95.9 & 95.8 & 96.0 & 95.9 \\
\hline
\end{tabular}

Taken together, we argue that our analysis is consistent with the notion that corporate investment plays a role in shaping stock liquidity by decreasing the risk of a stock. According to Berk et al. (1999), optimal corporate investment can decrease the risk of a stock by converting growth options into assets in place. A number of asset pricing studies support this proposition in the time series or cross-sectional analysis of expected returns (Carlson et al., 2004; Zhang, 2005; Li et al., 2009; and Liu et al., 2009). Moreover, the market microstructure literature documents that a change in the risk affects the pricing strategy of market makers, leading to a change in the price impact, i.e. stock liquidity (Kyle, 1985). After all, our analysis provides the implication of the recent development of corporate investment research for the market microstructure literature by illustrating how stock liquidity reacts to a change in the risk caused by corporate investment. To our best knowledge, this study is the first empirical analysis linking corporate investment to stock liquidity by emphasizing the risk shift from corporate investment.

It is interesting to compare our analysis with the implication of Gopalan et al. (2012). Consistent with the main seasonal equity offering (SEO) literature, Gopalan et al. (2012) implicitly argue that corporate investment increases asset risk in their analysis for the relationship between asset liquidity and stock liquidity. ${ }^{18}$ However, our analysis provides evidence on a positive role of corporate investment in affecting the risk, conforming to the real option-based explanation for SEO (Carlson et al., 2006). We point out that our study provides direct evidence on the causality between corporate investment and stock liquidity by investigating the effect of corporate investment on subsequent stock liquidity while Gopalan et al. (2012) illustrate the contemporary relationship between corporate investment and concurrent stock liquidity.

Overall, we discover the role of corporate investment in shaping stock liquidity. Moreover, we argue that corporate investment contributes to stock liquidity because optimal corporate investment decision leads to a decrease in the risk by interpreting the recent real option-based corporate investment study in the market microstructure context.

\subsection{The interaction effect with financial constraints}

In this section, we extend our analysis to investigate if corporate investment affects stock liquidity universally. In other words, we examine what factors influence the effect of corporate investment on stock liquidity. Specifically, we test the effect of financial constraints on the relationship between corporate investment and stock liquidity.

Since Fazzari et al. (1988) document the effect of financial constraints on corporate investment, many studies investigate the relationship between imperfect capital market and corporate investment. According to Fazzari et al. (1988), financial constraints prevent firms from financing all the desired investments. Therefore, financiallyconstrained firms are likely to show a low sensitivity of corporate investment to profitable investment opportunities other things equal, as shown in Kaplan and Zingales (1997). In other words, given the level of corporate investment, investment opportunities are likely to be more profitable for financially-constrained firms than for financiallyunconstrained firms. Based on this inference, we hypothesize that given any change in corporate investment, financially-constrained firms are likely to experience a greater risk shift and show a stronger effect of corporate investment on stock liquidity. ${ }^{19}$

We use two financial constraints variables: the Kaplan and Zingales (1997; KZ) index and firm size. For the KZ index, following Baker et al. (2003), we use the revised $\mathrm{KZ}$ index, a composite index based on cash flow (CF), cash dividend (DIV), cash balance (CB), and leverage (LEV),

\footnotetext{
18 See Ritter (2003) for the implication of corporate investment for the fundamental risk. Ritter (2003) argue that lower leverage from equity offerings is more than offset by increased operating risk, leading to a decrease in expected returns if issuing companies embark on aggressive expansion plans with the money raised in an SEO. Thus, our finding is not in line with the main SEO literature but with the real option-based explanation on SEOs.
}

\footnotetext{
19 However, Titman et al. (2005) illustrate a weaker effect of corporate investment on expected returns for financially-constrained firms. Titman et al. (2005) interpret firms with less financial flexibility as firms with less investment discretion and expect financially-constrained firms to show weaker return reversals, based on the behaviora
} finance. 
Table 5

Corporate investment and stock liquidity for financial constraints ( $K Z$ index).

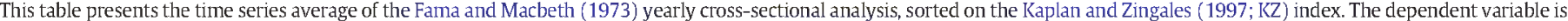

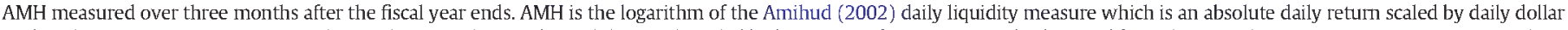

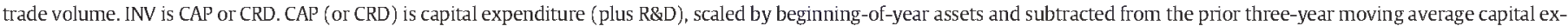

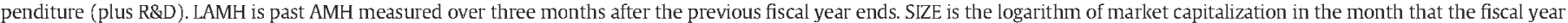

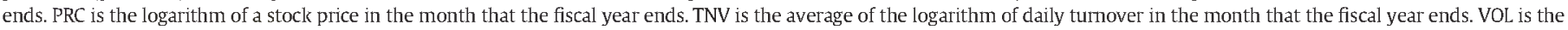

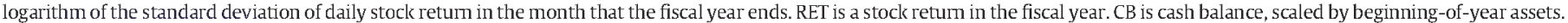
The Newey and West (1987) standard error corrected $t$-statistics are presented in parentheses. The sample spans the year of 1971 to 2012.

\begin{tabular}{|c|c|c|c|c|c|c|}
\hline & \multicolumn{3}{|l|}{ CAP } & \multicolumn{3}{|l|}{ CRD } \\
\hline & High & Low & Diff & High & Low & Diff \\
\hline Const. & $\begin{array}{l}-5.795 \\
(-34.30)\end{array}$ & $\begin{array}{l}-5.625 \\
(-29.20)\end{array}$ & $\begin{array}{l}-0.170 \\
(-2.08)\end{array}$ & $\begin{array}{l}-5.794 \\
(-34.30)\end{array}$ & $\begin{array}{l}-5.628 \\
(-29.18)\end{array}$ & $\begin{array}{l}-0.166 \\
(-2.02)\end{array}$ \\
\hline INV & $\begin{array}{l}-0.132 \\
(-3.06)\end{array}$ & $\begin{array}{l}-0.024 \\
(-0.62)\end{array}$ & $\begin{array}{l}-0.108 \\
(-1.98)\end{array}$ & $\begin{array}{l}-0.114 \\
(-2.82)\end{array}$ & $\begin{array}{l}-0.012 \\
(-0.35)\end{array}$ & $\begin{array}{l}-0.102 \\
(-2.05)\end{array}$ \\
\hline LAMH & $\begin{array}{l}0.144 \\
(9.02)\end{array}$ & $\begin{array}{l}0.187 \\
(10.97)\end{array}$ & $\begin{array}{l}-0.043 \\
(-5.35)\end{array}$ & $\begin{array}{l}0.144 \\
(9.01)\end{array}$ & $\begin{array}{l}0.188 \\
(10.98)\end{array}$ & $\begin{array}{l}-0.043 \\
(-5.36)\end{array}$ \\
\hline SIZE & $\begin{array}{l}-0.902 \\
(-49.65)\end{array}$ & $\begin{array}{l}-0.850 \\
(-52.43)\end{array}$ & $\begin{array}{l}-0.052 \\
(-5.81)\end{array}$ & $\begin{array}{l}-0.902 \\
(-49.63)\end{array}$ & $\begin{array}{l}-0.850 \\
(-52.54)\end{array}$ & $\begin{array}{l}-0.053 \\
(-5.83)\end{array}$ \\
\hline PRC & $\begin{array}{l}-0.265 \\
(-9.11)\end{array}$ & $\begin{array}{l}-0.216 \\
(-9.98)\end{array}$ & $\begin{array}{l}-0.049 \\
(-3.03)\end{array}$ & $\begin{array}{l}-0.265 \\
(-9.11)\end{array}$ & $\begin{array}{l}-0.216 \\
(-9.98)\end{array}$ & $\begin{array}{l}-0.049 \\
(-3.03)\end{array}$ \\
\hline TNV & $\begin{array}{l}-0.706 \\
(-47.43)\end{array}$ & $\begin{array}{l}-0.683 \\
(-44.46)\end{array}$ & $\begin{array}{l}-0.023 \\
(-2.91)\end{array}$ & $\begin{array}{l}-0.706 \\
(-47.41)\end{array}$ & $\begin{array}{l}-0.683 \\
(-44.40)\end{array}$ & $\begin{array}{l}-0.022 \\
(-2.89)\end{array}$ \\
\hline VOL & $\begin{array}{l}0.393 \\
(12.42)\end{array}$ & $\begin{array}{l}0.401 \\
(16.11)\end{array}$ & $\begin{array}{l}-0.008 \\
(-0.50)\end{array}$ & $\begin{array}{l}0.392 \\
(12.40)\end{array}$ & $\begin{array}{l}0.401 \\
(16.06)\end{array}$ & $\begin{array}{l}-0.008 \\
(-0.50)\end{array}$ \\
\hline RET & $\begin{array}{l}-0.173 \\
(-5.08)\end{array}$ & $\begin{array}{l}-0.196 \\
(-6.45)\end{array}$ & $\begin{array}{l}0.023 \\
(1.20)\end{array}$ & $\begin{array}{l}-0.173 \\
(-5.08)\end{array}$ & $\begin{array}{l}-0.196 \\
(-6.45)\end{array}$ & $\begin{array}{l}0.023 \\
(1.18)\end{array}$ \\
\hline $\mathrm{CB}$ & $\begin{array}{l}-0.116 \\
(-3.08)\end{array}$ & $\begin{array}{l}-0.084 \\
(-3.42)\end{array}$ & $\begin{array}{l}-0.033 \\
(-0.87)\end{array}$ & $\begin{array}{l}-0.117 \\
(-3.10)\end{array}$ & $\begin{array}{l}-0.084 \\
(-3.44)\end{array}$ & $\begin{array}{l}-0.033 \\
(-0.87)\end{array}$ \\
\hline Adj. R-squared (\%) & 95.1 & 96.4 & & 95.1 & 96.4 & \\
\hline
\end{tabular}

normalized by beginning-of-year book asset. The index is defined as follows.

$K Z_{i, t}=-1.002 C F_{i, t}-39.368 D I V_{i, t}-1.315 C B_{i, t}+3.139 L E V_{i, t}$

Moreover, we assume that financial constraints are also related to firm size measured by sales level, consistent with Gopalan et al.
(2012). Therefore, financially-constrained firms are characterized with high KZ-index score or small size.

We implement this analysis by examining whether corporate investment shows a different effect on stock liquidity across financial constraints. That is, we sort a universe of stocks into two groups based on financial constraints every year. Then, we run a separate regression for each group and compare the sensitivity of stock liquidity to corporate investment. In particular, we run the Fama and Macbeth (1973) cross-sectional regression

Table 6

Corporate investment and stock liquidity for financial constraints (firm size)

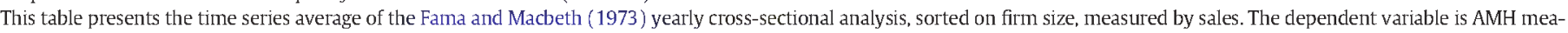

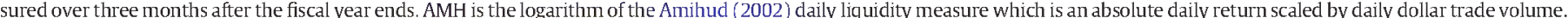

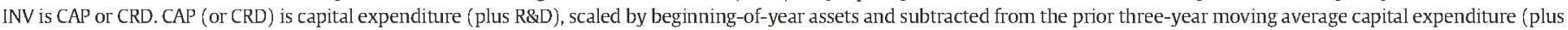

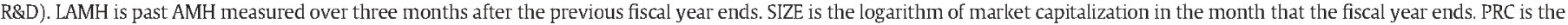

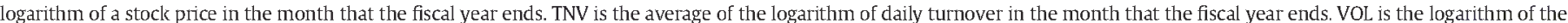

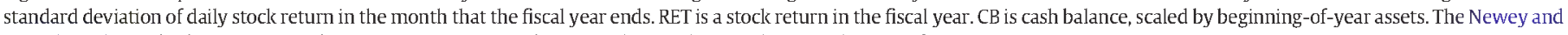
West (1987) standard error corrected $t$-statistics are presented in parentheses. The sample spans the year of 1971 to 2012.

\begin{tabular}{|c|c|c|c|c|c|c|}
\hline & \multicolumn{3}{|l|}{ CAP } & \multicolumn{3}{|l|}{ CRD } \\
\hline & Small & Big & Diff & Small & Big & Diff \\
\hline Const. & $\begin{array}{l}-5.579 \\
(-29.69)\end{array}$ & $\begin{array}{l}-5.960 \\
(-37.57)\end{array}$ & $\begin{array}{l}0.381 \\
(2.68)\end{array}$ & $\begin{array}{l}-5.578 \\
(-29.58)\end{array}$ & $\begin{array}{l}-5.960 \\
(-37.59)\end{array}$ & $\begin{array}{l}0.382 \\
(2.67)\end{array}$ \\
\hline INV & $\begin{array}{l}-0.111 \\
(-3.15)\end{array}$ & $\begin{array}{l}-0.040 \\
(-0.70)\end{array}$ & $\begin{array}{l}-0.071 \\
(-1.38)\end{array}$ & $\begin{array}{l}-0.079 \\
(-2.22)\end{array}$ & $\begin{array}{l}-0.021 \\
(-0.40)\end{array}$ & $\begin{array}{l}-0.057 \\
(-1.24)\end{array}$ \\
\hline LAMH & $\begin{array}{l}0.152 \\
(9.11)\end{array}$ & $\begin{array}{l}0.177 \\
(11.47)\end{array}$ & $\begin{array}{l}-0.025 \\
(-3.83)\end{array}$ & $\begin{array}{l}0.152 \\
(9.12)\end{array}$ & $\begin{array}{l}0.177 \\
(11.45)\end{array}$ & $\begin{array}{l}-0.025 \\
(-3.79)\end{array}$ \\
\hline SIZE & $\begin{array}{l}-0.895 \\
(-34.70)\end{array}$ & $\begin{array}{l}-0.851 \\
(-56.74)\end{array}$ & $\begin{array}{l}-0.044 \\
(-2.51)\end{array}$ & $\begin{array}{l}-0.895 \\
(-34.71)\end{array}$ & $\begin{array}{l}-0.851 \\
(-56.61)\end{array}$ & $\begin{array}{l}-0.044 \\
(-2.51)\end{array}$ \\
\hline PRC & $\begin{array}{l}-0.249 \\
(-7.59)\end{array}$ & $\begin{array}{l}-0.226 \\
(-9.61)\end{array}$ & $\begin{array}{l}-0.023 \\
(-1.20)\end{array}$ & $\begin{array}{l}-0.249 \\
(-7.60)\end{array}$ & $\begin{array}{l}-0.226 \\
(-9.62)\end{array}$ & $\begin{array}{l}-0.023 \\
(-1.20)\end{array}$ \\
\hline TNV & $\begin{array}{l}-0.683 \\
(-48.45)\end{array}$ & $\begin{array}{l}-0.702 \\
(-46.58)\end{array}$ & $\begin{array}{l}0.020 \\
(2.54)\end{array}$ & $\begin{array}{l}-0.683 \\
(-48.44)\end{array}$ & $\begin{array}{l}-0.703 \\
(-46.49)\end{array}$ & $\begin{array}{l}0.020 \\
(2.55)\end{array}$ \\
\hline VOL & $\begin{array}{l}0.392 \\
(12.54)\end{array}$ & $\begin{array}{l}0.394 \\
(13.19)\end{array}$ & $\begin{array}{l}-0.001 \\
(-0.06)\end{array}$ & $\begin{array}{l}0.392 \\
(12.52)\end{array}$ & $\begin{array}{l}0.394 \\
(13.19)\end{array}$ & $\begin{array}{l}-0.001 \\
(-0.07)\end{array}$ \\
\hline RET & $\begin{array}{l}-0.202 \\
(-5.93)\end{array}$ & $\begin{array}{l}-0.172 \\
(-5.70)\end{array}$ & $\begin{array}{l}-0.030 \\
(-1.67)\end{array}$ & $\begin{array}{l}-0.202 \\
(-5.94)\end{array}$ & $\begin{array}{l}-0.172 \\
(-5.68)\end{array}$ & $\begin{array}{l}-0.030 \\
(-1.69)\end{array}$ \\
\hline $\mathrm{CB}$ & $\begin{array}{l}-0.099 \\
(-4.48)\end{array}$ & $\begin{array}{l}-0.010 \\
(-0.30)\end{array}$ & $\begin{array}{l}-0.089 \\
(-3.23)\end{array}$ & $\begin{array}{l}-0.100 \\
(-4.53)\end{array}$ & $\begin{array}{l}-0.011 \\
(-0.33)\end{array}$ & $\begin{array}{l}-0.089 \\
(-3.24)\end{array}$ \\
\hline Adj. R-squared (\%) & 91.0 & 95.7 & & 91.0 & 95.7 & \\
\hline
\end{tabular}


Table 7

Change in return volatility and corporate investment.

This table presents the time-series average of the coefficient in the Fama and Macbeth (1973) yearly regression. Except for corporate investment (INV), each variable is a change in characteristics measured between the month that the fiscal year ends and three months after the fiscal year ends. The dependent variable is a change in the logarithm of the standard deviation of daily stock return. DTNV/D PRC is a change in the logarithm of the average daily tumover/a stock price. INV is CAP (or CRD) which is capital expenditure (plus R\&D) scaled by assets. The $t$-statistics are presented below the coefficients. The Newey and West (1987) standard error corrected $t$-statistics are presented in parentheses. The sample spans the year of 1971 to 2012

\begin{tabular}{lll}
\hline & CAP & CRD \\
\hline Const. & -0.005 & -0.005 \\
DTNV & $(-0.61)$ & $(-0.63)$ \\
& 0.275 & 0.275 \\
DPRC & $(20.39)$ & $(20.38)$ \\
INV & -0.422 & -0.422 \\
Adj. R-squared (\%) & $(-18.28)$ & $(-18.26)$ \\
& $(-0.035$ & -0.034 \\
\hline
\end{tabular}

for AMH measured over three months after the fiscal year ends. ${ }^{20}$ Tables 5 and 6 present the result for each group and the difference between two groups sorted on the $\mathrm{KZ}$ index and firm size, respectively.

The following are noticeable findings. On one hand, stock liquidity is more sensitive to several determinants for financially-constrained firms. We observe this regularity for both financial constraints variables, as shown in Tables 5 and 6. It is because those determinants also relate to the fundamental risk. Financially-constrained firms are so vulnerable to the fundamental risk that market makers respond more strongly to a variation in the fundamental risk for financially-constrained firms, showing a bigger change in stock liquidity. ${ }^{21}$

On the other hand, corporate investment has a stronger effect on stock liquidity for financially-constrained firms. That is, we find that financiallyconstrained firms drive the corporate investment-stock liquidity pattern in Tables 5 and 6 . Specifically, high KZ-index or small firms exhibit a significant effect of corporate investment on stock liquidity while low KZindex or big firms show a weaker effect. For example, Table 5 shows that the coefficient of INV is -0.132 (or -0.114 ) with a t-statistic of -3.06 (or -2.82 ) for CAP (or CRD) in the regression of high KZ-index firms. However, the coefficient of INV is just -0.024 (or -0.12 ) with a t-statistic of -0.62 (or -0.35 ) for CAP (or CRD) in the analysis of low $\mathrm{KZ}$-index firms. Moreover, we also observe a significant difference in the effect of corporate investment between high and low KZ-index firms with a t-statistic of -1.98 for CAP and -2.05 for CRD, respectively.

Table 6 presents the same pattern for the analysis sorted on firm size. That is, small firms show a significant effect of corporate investment on stock liquidity with the coefficient of INV of -0.111 (or -0.079 ) and a t-statistic of $-3.15(-2.22)$ for CAP (or CRD) while big firms exhibit a weaker effect with the coefficient of INV of -0.040 (or -0.021 ) and a t-statistic of -0.70 (or -0.40 ) for CAP (or CRD). However, there is no significant difference in the effect of corporate investment between small and big firms in Table 6.

Overall, our analysis confirms that there is an interaction effect between financial constraints and corporate investment in the context of stock liquidity. Specifically, we show that financially-constrained firms drive the corporate investment-stock liquidity pattern. We argue that this analysis is also consistent with our risk-based interpretation for the relationship between corporate investment and stock liquidity. As the literature addresses (Whited \& Wu, 2006; Gomes, Yaron, \& Lu,

\footnotetext{
${ }^{20}$ We obtain qualitatively the same results for AMH measured over one or two months after the fiscal year ends.

21 Several stock liquidity determinants, such as firm size, stock price, turnover, or cash balance, are also major explanatory variables for firm's expected returns. Moreover, Whited and Wu (2006), Gomes et al. (2006), and Livdan et al. (2009) address the effect of financial constraints risk on expected returns.
}

2006), financial constraints can affect, specifically increase, expected return. Thus, an increase in the cost of capital leads firms to accept investment opportunities with a higher internal rate of return. After all, financially-constrained firms are likely to take on more profitable investment opportunities given the corporate investment. Therefore, when a risk shift occurs, financially-constrained firms are likely to exhibit stronger improvement in stock liquidity. Taken together, the current analysis strengthens our risk-based interpretation for the role of corporate investment in shaping stock liquidity.

\section{Robustness check}

In this section, we investigate whether our empirical regularity is robust to any alternative economic explanations. We summarize the findings as follows.

First, we examine whether optimal corporate investment indeed decreases the risk of a stock. According to Berk et al. (1999), corporate investment relates to mostly the systematic risk of a stock. Therefore, one might raise the possibility that higher corporate investment leads to lower systematic risk, not lower total risk, questioning the implication for stock liquidity. We address this issue in two approaches. The first approach is to highlight the recent literature on stock liquidity. This line of studies provides evidence on a negative association between the systematic component of the risk and stock liquidity. (Brunnermeier \& Pedersen, 2009; Comerton-Forde, Hendershott, Jones, Moulton, \& Seaholes, 2010; Nagel, 2012) Therefore, these studies imply that stock liquidity is not immune to a change in systematic risk even though corporate investment affects systematic risk only. The second approach demonstrates the effect of corporate investment on total risk. Thus, we empirically investigate whether corporate investment contributes to stock return volatility. Table 7 presents a result for the cross-sectional regression of a change in return volatility on corporate investment. At a significance level of $10 \%$ for a one-sided test, stock return volatility is likely to decrease for firms with high corporate investment even after controlling for other well-known relevant variables such as trade volume and stock returns. Taken together, corporate investment indeed decreases the risk, both total and systematic risk.

Second, we investigate the feedback effect of stock liquidity on corporate investment. The literature documents that a positive shock on stock liquidity leads to a decrease in the cost of equity, which in turn expands the set of profitable investment opportunities and increases corporate investment. (Becker-Blease \& Paul, 2006; Derrien \& Kecskes, 2013) Given this reverse causality, we might suspect that there is an endogeneity problem. We examine this issue in two ways. First, we investigate whether our measure for corporate investment indeed reflects prior stock liquidity. Following Baker et al. (2003), we estimate corporate investment based on a marginal $q$, the market-to-book value ratio of equity, and current cash flow in the cross-sectional regression. The result is shown in Table 8 . Stock liquidity has a marginal or insignificant effect on our measure for corporate investment, 'abnormal' corporate investment, as shown in Panel B of Table 8, while prior stock liquidity indeed significantly increases 'raw' corporate investment in Panel A. That is, our measure for corporate investment is not subject to the feedback effect of stock liquidity. Second, we directly control for endogeneity problem by using the two-stage least square (2SLS) analysis. Following the existing corporate investment literature, i.e. Baker et al. (2003), we employ the market-to-book value ratio of equity and the current cash flow as instrument variables in the first-stage regression. Table 9 shows the result for the two-stage least square (2SLS) analysis. The second and fourth columns present the 2SLS analysis for stock liquidity while the first and third columns show the first-stage regression for corporate investment. In summary, the 2SLS does not change the result of the original analysis in Table 4 except for some changes in stock return and cash balance, confirming our main findings. ${ }^{22}$

\footnotetext{
${ }^{22}$ We check the validity of instrument variables. The result is available upon request
} 
Table 8

The feedback effect of stock liquidity on corporate investment.

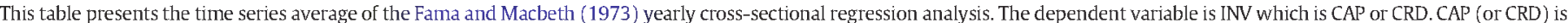

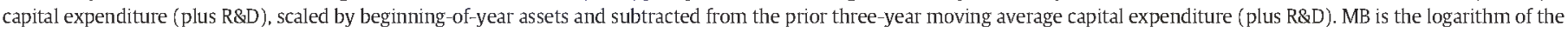

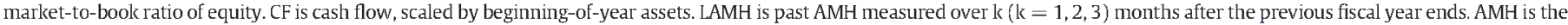

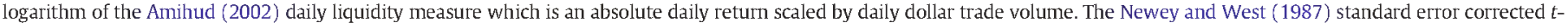
statistics are presented in parentheses. The sample spans the year of 1971 to 2012.

\begin{tabular}{|c|c|c|c|c|c|c|}
\hline & \multicolumn{6}{|c|}{ Panel A: Nominal INV } \\
\hline & \multicolumn{3}{|l|}{ CAP } & \multicolumn{3}{|l|}{ CRD } \\
\hline & 1 month & 2 month & 3 month & 1 month & 2 month & 3 month \\
\hline Const. & $\begin{array}{l}-0.061 \\
(-4.36)\end{array}$ & $\begin{array}{l}-0.061 \\
(-4.38)\end{array}$ & $\begin{array}{l}-0.061 \\
(-4.42)\end{array}$ & $\begin{array}{l}-0.189 \\
(-10.02)\end{array}$ & $\begin{array}{l}-0.189 \\
(-10.07)\end{array}$ & $\begin{array}{l}-0.190 \\
(-10.12)\end{array}$ \\
\hline MB & $\begin{array}{l}0.014 \\
(6.08)\end{array}$ & $\begin{array}{l}0.014 \\
(6.10)\end{array}$ & $\begin{array}{l}0.014 \\
(6.11)\end{array}$ & $\begin{array}{l}0.036 \\
(9.19)\end{array}$ & $\begin{array}{l}0.036 \\
(9.22)\end{array}$ & $\begin{array}{l}0.036 \\
(9.25)\end{array}$ \\
\hline $\mathrm{CF}$ & $\begin{array}{l}0.240 \\
(5.19)\end{array}$ & $\begin{array}{l}0.240 \\
(5.19)\end{array}$ & $\begin{array}{l}0.239 \\
(5.19)\end{array}$ & $\begin{array}{l}0.083 \\
(1.01)\end{array}$ & $\begin{array}{l}0.083 \\
(1.00)\end{array}$ & $\begin{array}{l}0.082 \\
(1.00)\end{array}$ \\
\hline LAMH & $\begin{array}{l}-0.001 \\
(-2.33)\end{array}$ & $\begin{array}{l}-0.001 \\
(-2.28)\end{array}$ & $\begin{array}{l}-0.001 \\
(-2.36)\end{array}$ & $\begin{array}{l}-0.001 \\
(-2.41)\end{array}$ & $\begin{array}{l}-0.002 \\
(-2.56)\end{array}$ & $\begin{array}{l}-0.002 \\
(-2.69)\end{array}$ \\
\hline \multirow[t]{4}{*}{ Adj. R-squared (\%) } & 10.5 & 10.5 & 10.5 & 18.2 & 18.3 & 18.2 \\
\hline & \multicolumn{6}{|c|}{ Panel B: INV } \\
\hline & \multicolumn{3}{|l|}{ CAP } & \multicolumn{3}{|l|}{ CRD } \\
\hline & 1 month & 2 month & 3 month & 1 month & 2 month & 3 month \\
\hline Const. & $\begin{array}{l}0.026 \\
(0.68)\end{array}$ & $\begin{array}{l}0.026 \\
(0.67)\end{array}$ & $\begin{array}{l}0.025 \\
(0.65)\end{array}$ & $\begin{array}{l}0.060 \\
(1.34)\end{array}$ & $\begin{array}{l}0.059 \\
(1.33)\end{array}$ & $\begin{array}{l}0.058 \\
(1.31)\end{array}$ \\
\hline MB & $\begin{array}{l}-0.010 \\
(-1.43)\end{array}$ & $\begin{array}{l}-0.010 \\
(-1.46)\end{array}$ & $\begin{array}{l}-0.010 \\
(-1.48)\end{array}$ & $\begin{array}{l}-0.016 \\
(-1.99)\end{array}$ & $\begin{array}{l}-0.016 \\
(-2.03)\end{array}$ & $\begin{array}{l}-0.016 \\
(-2.05)\end{array}$ \\
\hline $\mathrm{CF}$ & $\begin{array}{l}0.136 \\
(6.08)\end{array}$ & $\begin{array}{l}0.135 \\
(6.08)\end{array}$ & $\begin{array}{l}0.135 \\
(6.06)\end{array}$ & $\begin{array}{l}0.153 \\
(5.99)\end{array}$ & $\begin{array}{l}0.152 \\
(5.98)\end{array}$ & $\begin{array}{l}0.152 \\
(5.96)\end{array}$ \\
\hline LAMH & $\begin{array}{l}-0.001 \\
(-1.32)\end{array}$ & $\begin{array}{l}-0.001 \\
(-1.42)\end{array}$ & $\begin{array}{l}-0.001 \\
(-1.53)\end{array}$ & $\begin{array}{l}-0.002 \\
(-1.54)\end{array}$ & $\begin{array}{l}-0.002 \\
(-1.69)\end{array}$ & $\begin{array}{l}-0.002 \\
(-1.82)\end{array}$ \\
\hline Adj. R-squared (\%) & 2.0 & 2.0 & 2.0 & 2.5 & 2.5 & 2.5 \\
\hline
\end{tabular}

Third, we examine if stock liquidity improves due to equity financing accompanying corporate investment. The reason is as follows. Equity capital is often a major source for financing corporate investment. Moreover, an increase in equity capital itself, i.e. seasoned equity

offerings, leads to an increase in stock liquidity, as shown in Eckbo et al. (2000). Thus, one might suspect that an increase in stock liquidity is attributable to equity financing, not corporate investment. To investigate this alternative explanation, we control for equity financing by

Table $\mathbf{g}$

Corporate investment and stock liquidity: 2 SLS analysis.

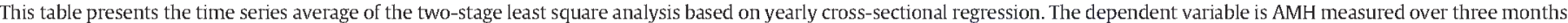

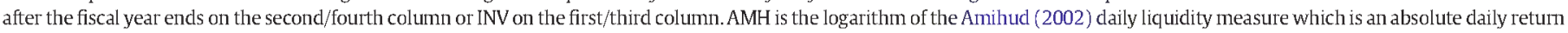

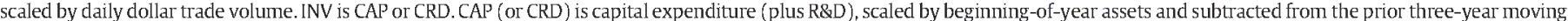

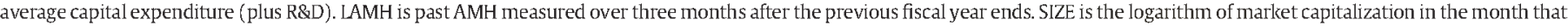

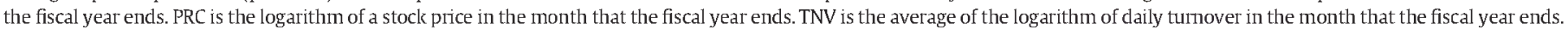

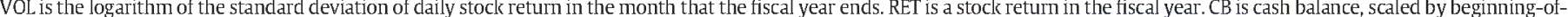

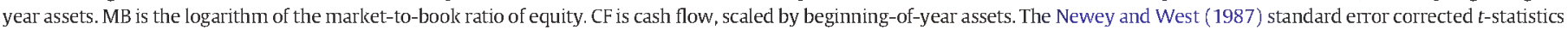
are presented in parentheses. The sample spans the year of 1971 to 2012.

\begin{tabular}{|c|c|c|c|c|}
\hline & \multicolumn{2}{|l|}{ CAP } & \multicolumn{2}{|l|}{ CRD } \\
\hline & First-stage & 2SLS & First-stage & 2SLS \\
\hline Const. & $\begin{array}{l}-0.054 \\
(-2.00)\end{array}$ & $\begin{array}{l}-6.035 \\
(-33.13)\end{array}$ & $\begin{array}{l}-0.036 \\
(-0.92)\end{array}$ & $\begin{array}{l}-5.979 \\
(-24.76)\end{array}$ \\
\hline INV & & $\begin{array}{l}-3.880 \\
(-2.03)\end{array}$ & & $\begin{array}{l}-3.009 \\
(-2.01)\end{array}$ \\
\hline LAMH & $\begin{array}{l}-0.004 \\
(-1.52)\end{array}$ & $\begin{array}{l}0.154 \\
(10.97)\end{array}$ & $\begin{array}{l}-0.001 \\
(-0.30)\end{array}$ & $\begin{array}{l}0.156 \\
(9.97)\end{array}$ \\
\hline SIZE & $\begin{array}{l}-0.009 \\
(-2.35)\end{array}$ & $\begin{array}{l}-0.903 \\
(-56.35)\end{array}$ & $\begin{array}{l}-0.006 \\
(-1.30)\end{array}$ & $\begin{array}{l}-0.898 \\
(-49.46)\end{array}$ \\
\hline PRC & $\begin{array}{l}0.012 \\
(5.85)\end{array}$ & $\begin{array}{l}-0.181 \\
(-4.10)\end{array}$ & $\begin{array}{l}0.017 \\
(7.08)\end{array}$ & $\begin{array}{l}-0.204 \\
(-8.04)\end{array}$ \\
\hline TNV & $\begin{array}{l}-0.003 \\
(-1.28)\end{array}$ & $\begin{array}{l}-0.713 \\
(-47.14)\end{array}$ & $\begin{array}{l}-0.002 \\
(-0.42)\end{array}$ & $\begin{array}{l}-0.712 \\
(-40.57)\end{array}$ \\
\hline VOL & $\begin{array}{l}-0.004 \\
(-1.83)\end{array}$ & $\begin{array}{l}0.378 \\
(13.27)\end{array}$ & $\begin{array}{l}-0.005 \\
(-1.88)\end{array}$ & $\begin{array}{l}0.370 \\
(11.85)\end{array}$ \\
\hline RET & $\begin{array}{l}0.013 \\
(5.00)\end{array}$ & $\begin{array}{l}-0.095 \\
(-1.57)\end{array}$ & $\begin{array}{l}0.006 \\
(0.61)\end{array}$ & $\begin{array}{l}-0.143 \\
(-2.61)\end{array}$ \\
\hline$C B$ & $\begin{array}{l}0.004 \\
(0.49)\end{array}$ & $\begin{array}{l}0.045 \\
(0.62)\end{array}$ & $\begin{array}{l}-0.011 \\
(-1.02)\end{array}$ & $\begin{array}{l}-0.037 \\
(-0.65)\end{array}$ \\
\hline MB & $\begin{array}{l}-0.011 \\
(-1.42)\end{array}$ & & $\begin{array}{l}-0.019 \\
(-2.25)\end{array}$ & \\
\hline $\mathrm{CF}$ & $\begin{array}{l}0.095 \\
(4.26)\end{array}$ & & $\begin{array}{l}0.100 \\
(3.68)\end{array}$ & \\
\hline
\end{tabular}


Table 10

Corporate investment and stock liquidity for equity financing.

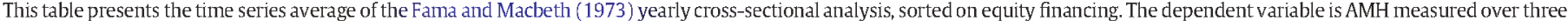

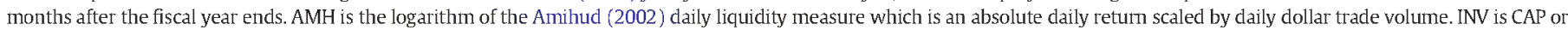

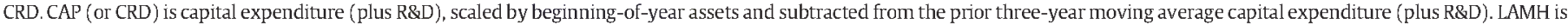

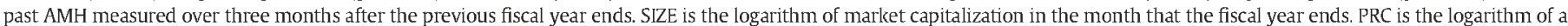

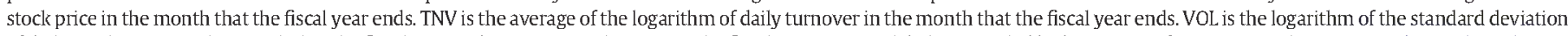

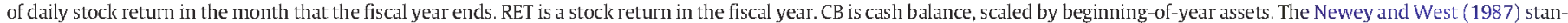
dard error corrected $t$-statistics are presented in parentheses. The sample spans the year of 1971 to 2012.

\begin{tabular}{|c|c|c|c|c|c|c|}
\hline & \multicolumn{3}{|l|}{$\mathrm{CAP}$} & \multicolumn{3}{|l|}{ CRD } \\
\hline & No & Yes & Diff & No & Yes & Diff \\
\hline Const. & $\begin{array}{l}-5.564 \\
(-31.04)\end{array}$ & $\begin{array}{l}-5.872 \\
(-33.09)\end{array}$ & $\begin{array}{l}0.309 \\
(3.11)\end{array}$ & $\begin{array}{l}-5.564 \\
(-31.07)\end{array}$ & $\begin{array}{l}-5.873 \\
(-33.06)\end{array}$ & $\begin{array}{l}0.309 \\
(3.12)\end{array}$ \\
\hline INV & $\begin{array}{l}-0.122 \\
(-2.14)\end{array}$ & $\begin{array}{l}-0.058 \\
(-1.40)\end{array}$ & $\begin{array}{l}-0.064 \\
(-1.07)\end{array}$ & $\begin{array}{l}-0.109 \\
(-1.99)\end{array}$ & $\begin{array}{l}-0.052 \\
(-1.32)\end{array}$ & $\begin{array}{l}-0.057 \\
(-0.96)\end{array}$ \\
\hline LAMH & $\begin{array}{l}0.196 \\
(11.91)\end{array}$ & $\begin{array}{l}0.136 \\
(8.28)\end{array}$ & $\begin{array}{l}0.061 \\
(5.89)\end{array}$ & $\begin{array}{l}0.197 \\
(11.95)\end{array}$ & $\begin{array}{l}0.136 \\
(8.26)\end{array}$ & $\begin{array}{l}0.061 \\
(5.93)\end{array}$ \\
\hline SIZE & $\begin{array}{l}-0.839 \\
(-52.13)\end{array}$ & $\begin{array}{l}-0.912 \\
(-47.76)\end{array}$ & $\begin{array}{l}0.073 \\
(6.55)\end{array}$ & $\begin{array}{l}-0.839 \\
(-52.29)\end{array}$ & $\begin{array}{l}-0.912 \\
(-47.75)\end{array}$ & $\begin{array}{l}0.073 \\
(6.59)\end{array}$ \\
\hline PRC & $\begin{array}{l}-0.238 \\
(-8.96)\end{array}$ & $\begin{array}{l}-0.231 \\
(-10.35)\end{array}$ & $\begin{array}{l}-0.008 \\
(-0.59)\end{array}$ & $\begin{array}{l}-0.238 \\
(-8.95)\end{array}$ & $\begin{array}{l}-0.231 \\
(-10.38)\end{array}$ & $\begin{array}{l}-0.007 \\
(-0.58)\end{array}$ \\
\hline TNV & $\begin{array}{l}-0.679 \\
(-43.64)\end{array}$ & $\begin{array}{l}-0.705 \\
(-49.46)\end{array}$ & $\begin{array}{l}0.026 \\
(2.85)\end{array}$ & $\begin{array}{l}-0.679 \\
(-43.68)\end{array}$ & $\begin{array}{l}-0.705 \\
(-49.47)\end{array}$ & $\begin{array}{l}0.026 \\
(2.86)\end{array}$ \\
\hline VOL & $\begin{array}{l}0.387 \\
(13.55)\end{array}$ & $\begin{array}{l}0.405 \\
(13.58)\end{array}$ & $\begin{array}{l}-0.018 \\
(-1.18)\end{array}$ & $\begin{array}{l}0.387 \\
(13.50)\end{array}$ & $\begin{array}{l}0.405 \\
(13.59)\end{array}$ & $\begin{array}{l}-0.018 \\
(-1.19)\end{array}$ \\
\hline RET & $\begin{array}{l}-0.252 \\
(-7.97)\end{array}$ & $\begin{array}{l}-0.137 \\
(-4.91)\end{array}$ & $\begin{array}{l}-0.115 \\
(-6.48)\end{array}$ & $\begin{array}{l}-0.252 \\
(-7.99)\end{array}$ & $\begin{array}{l}-0.137 \\
(-4.90)\end{array}$ & $\begin{array}{l}-0.115 \\
(-6.55)\end{array}$ \\
\hline $\mathrm{CB}$ & $\begin{array}{l}-0.032 \\
(-0.97)\end{array}$ & $\begin{array}{l}-0.078 \\
(-3.12)\end{array}$ & $\begin{array}{l}0.046 \\
(1.62)\end{array}$ & $\begin{array}{l}-0.033 \\
(-1.01)\end{array}$ & $\begin{array}{l}-0.079 \\
(-3.16)\end{array}$ & $\begin{array}{l}0.045 \\
(1.60)\end{array}$ \\
\hline Adj. R-squared (\%) & 96.1 & 95.2 & & 96.1 & 95.2 & \\
\hline
\end{tabular}

sorting stocks into two groups based on net equity financing and comparing these two groups in a separate regression. Table 10 presents the analysis. On one hand, we find that equity financing indeed affects stock liquidity. In other words, unconditional stock liquidity is higher for firms with equity financing. In the analysis of CAP, a constant term is -5.872 for firms with equity financing while it is -5.564 for firms with no equity financing. Moreover, the difference is statistically significant with a t-statistic of -3.11 . We observe the same pattern for CRD. This outcome is consistent with Eckbo et al. (2000). On the other hand, we obtain an interesting outcome. That is, corporate investment has a significant effect on stock liquidity only for firms with no equity financing. For example, the coefficient of INV is -0.122 (or -0.109 ) with a $t$ statistic of -2.14 (or -1.99 ) for CAP (or CRD) in the regression of firms with no equity financing. On the other hand, the coefficient of INV is just -0.058 (or -0.052 ) with a t-statistic of -1.40 (or -1.32 ) for CAP (or CRD) in the analysis of firms with equity financing. Therefore, this analysis addresses that an increase in stock liquidity is attributable to corporate investment as well as equity financing.

\section{Conclusion}

The recent corporate investment literature argues that optimal corporate investment decreases the risk of a stock. Moreover, the market microstructure literature addresses that a change in the risk affects the pricing strategy of market makers, leading to a change in the price impact. In this study, we establish the relationship between corporate investment and stock liquidity by connecting the recent development of the corporate investment research to the market microstructure literature.

This study demonstrates that corporate investment contributes to stock liquidity by providing empirical evidence on the role corporate investment in shaping stock liquidity. Moreover, we show that stock liquidity improves more apparently for firms with financial constraints because those firms are likely to experience a greater risk shift. After all, we argue that corporate investment decreases the risk of a firm which, in turn, causes a market maker to improve stock liquidity.

Our study complements a growing study on the determinants of stock liquidity by discovering a role of corporate investment in shaping stock liquidity. Moreover, our analysis is also relevant to the market efficiency literature because we can explore the link between corporate investment and a change in arbitrage activity or market anomaly by highlighting a role of corporate investment in stock liquidity.

\section{References}

Acharya, V., \& Pedersen, L. H. (2005). Asset pricing with liquidity risk. Journal of Financial Econonics, 77, 375-410.

Admati, A., \& Pfleiderer, P. (1988). A theory of intraday patterns: Volume and price variability. Review of Financial Studies, 1, 3-40.

Amihud, Y. (2002). Illiquidity and stock returns: Cross-section and time-series effects. Joumal of Financial Markets, 5, 31-56.

Baker, M., Stein, J., \& Wurgler, J. (2003). When does the market matter? Stock prices and the investment of equity dependent firms. Quarterly Joumal of Economics, 118 969-1006.

Becker-Blease, J., \& Paul, D. (2006). Stock liquidity and investment opportunities: Evidence from index additions. Financial Management, 35, 35-51.

Berk, J., Green, R. C., \& Naik, V. (1999). Optimal investment, growth options, and security returns. Journal of Finance, 54, 1553-1607.

Bond, P., Edmans, A., \& Goldstein, I. (2012). The real effects of financial markets. Ammual Review of Financial Economics, 4, 339-360.

Brunnermeier, M., \& Pedersen, L. H. (2009). Market liquidity and funding liquidity. Review of Financial Studies, 22, 2201-2238.

Carlson, M., Fisher, A., \& Giammarino, R (2004). Corporate investment and asset price dynamics: Implications for the cross-section of returns. Journal of Finance, 59, 2577-2603.

Carlson, M., Fisher, A., \& Giammarino, R (2006). Corporate investment and asset price dynamics: Implications for SEO event studies and long run performance. Journal of Finance, 61, 1009-1034.

Comerton-Forde, C., Hendershott, T., Jones, C., Moulton, P., \& Seaholes, M. (2010). Time variation in liquidity: The role of market-maker inventories and revenues. Joumal of Finance, 65, 295-331.

Dertien, F., \& Kecskes, A. (2013). The real effects of financial shocks: Evidence from exog enous changes in analyst coverage. Journal of Finance, 68, 1407-1440.

Eckbo, B. E., Masulis, R. W., \& Norli, O. (2000). Seasoned public offerings: Resolution of the 'new issues puzzle'. Journal of Financial Economics, 56, 251-291.

Eisfeldt, L. A. (2004). Endogenous liquidity in asset markets. Journal of Finance, 59, 1-30.

Fama, E., \& Macbeth, J. (1973). Risk, return, and equilibrium-empirical tests. Journal of Political Economy, 83, 607-636.

Fazzari, S., Hubbard, R., \& Petersen, B. (1988). Financing constraints and corporate investment. Brookings Papers on Economic Activity, 141-195.

Glosten, L., \& Milgrom, P. (1985). Bid, ask and transaction prices in a specialist market with heterogeneously informed traders. Journal of Financial Economics, 14, 71-100.

Gomes, J., Yaron, A., \& Lu, Z. (2006). Asset pricing implications of firms' financing constraints. Review of Financial Studies, 19, 1321-1356.

Gopalan, R., Kadan, O., \& Pevzner, M. (2012). Asset liquidity and stock liquidity. Journal of Financial and Quantitative Analysis, 47, 333-363. 
Grossman, S., \& Miller, M. (1988). Liquidity and market structure. Journal of Finance, 43, $617-633$.

Hubbard, G. (1998). Capital market imperfections and investment. Journal of Economic Literature, 36, 193-225.

Kaplan, S., \& Zingales, L. (1997). Do investment-cash flow sensitivities provide useful measures of financing constraints? Quarterly Journal of Economics, 112, 169-215.

Kyle, A. (1985). Continuous auctions and insider trading. Econometrica, 53, 1315-1336.

Li, E., Livdan, D. \& Zhang, L. (2009). Anomalies. Review of Financial Studies, 22, 4301-4334.

Liu, L., Whited, T., \& Zhang, L. (2009). Investment-based expected stock retums. Joumal of Political Economy, 117, 1105-1139.

Livdan, D., Shapriza, H., \& Lu, Z. (2009). Financially constrained stock returns. Journal of Finance, 54, 1827-1862.

Nagel, S. (2012). Evaporating liquidity. Review of Financial Studies, 25, 2005-2039.
Newey, W. \& West, K. (1987). A simple, positive semi-definite, heteroskedasticity and autocorrelation consistent covariance matrix. Econometrica, 55, 703-708.

Ritter, J. (2003). Investment banking and securities issuance. Handbook of the Economics of Finance, 253-304.

Stein, J. (2003). Agency, information, and corporate investment. Handbook of the Economics of Finance, 1009-1163.

Titman, S., Wei, K., \& Xie, F. (2005). Capital investments and stock returns. Journal of Financial and Quantitative Analysis, 39, 677-700.

Whited, T. M., \& Wu, G. (2006). Financial constraints risk. Review of Financial Studies, 19. $531-559$.

Zhang, L. (2005). The value premium. Journal of Finance, 60, 67-103. 